УДК 327

DOI 10.30970/vir.2018.45.0.9455

\title{
PRZYSZLOŚĆ MIĘDZYNARODOWYCH REGULACJI DOTYCZĄCYCH DÓBR WSPÓLNYCH LUDZKOŚCI
}

\author{
Piotr Motyl \\ Uniwersytet im. Mikołaja Kopernika w Toruniu, \\ ul. Gagarina 11, Toruń, Polska, 87-100, \\ e-mail plm.motyl@interia.pl
}

Przyszłość dóbr wspólnych ludzkości oraz zabezpieczających je norm prawa międzynarodowego, staje się ważnym polem badań naukowych. Traktaty i nieformalne regulacje pochodzące z XX wieku nie wydają się być wystarczające w wieku XXI. W moim przekonaniu, w krótkim okresie, takie problemy jak wyścig o dostęp do surówców naturalnych Arktyki, Antarktyda, czy przestrzeń kosmiczna, staną się być może jeszcze ważniejsze z powodu szybkiego rozwoju technologii i zmian w strukturze stosunków międzynarodowych.

Nie tylko konkretne terytoria, ale również poszczególne obszary środowiska stanowią przedmiot uwagi i troski, np. dno morskie, odpady radioaktywne, podobnie jak różne rodzaje broni, mogące mieć charakter wyniszczający, na przykład broń chemiczna, biologiczna, atomowa. Stopień obligatoryjnych regulacji różni się często - od tylko deklaratywnego po istotnie wysoki. W artykule wskazuję na przyczyny różnic.

Tak jak wskazałem wyżej, stan obecny omawianych kwestii posiada swoją genezę w przeszłości, w związku z czym również ta perspektywa analizy jest bardzo istotna, począwszy co najmniej od okresu międzywojennego, przez Zimną Wojnę, ostatnia dekade XX wieku i początek wieku XXI. Polityka, ekonomia, rozwój technologiczny, przyniósł rezultat w takiej postaci, że część uregulowań powstała zbyt szybko, będąc raczej przykładem strachu przed wybuchem kolejnej wojny światowej, myślenia życzeniowego itd. Jakkolwiek od czasu do czasu rywalizacja, np. dwublokowa, dawała pozytywne rezultaty $\mathrm{w}$ omawianym przedmiocie, nie było moim zdaniem jednej pozytywnej albo negatywnej tendencji, podobnie do stanu relacji międzynarodowych zmieniających się w tym okresie wielokrotnie.

W artykule analizuję powyższe problemy i przedstawiam konkluzje, które uważam za najbardziej istotne. Główne metody badawcze których używam to porównanie regulacji formalnych i nieformalnych (jeżeli nie istnieją próbuję wyjaśnić dlaczego) z tym co można obserwować obecnie w praktyce. Analizę wspieram statystykami, raportami, informacjami wynikającymi z dociekań mediów.

Stowa kluczowe: dobra wspólne; ludzkość; prawo międzynarodowe; bezpieczeństwo międzynarodowe; ochrona środowiska.

\section{Wstęp}

W moim artykule chce się skupić przede wszystkim na obszarach niepodlegających jurysdykcji państw, niejednokrotnie również, podlegających tylko niewielkiej kontroli międzynarodowej na mocy traktatów, lub nieformalnej kontroli mającej swoje źródło w wypadkowej sił politycznych, gospodarczych, technologicznych i militarnych podmiotów zgłaszających do takich terytoriów rozszczenia o różnych charakterze. Odniose się do problemów Antarktydy, Arktyki, przestrzeni kosmicznej. Dwa pierwsze są siłą rzeczy problemami dominującymi nad

Motyl Piotr, 2018 
trzecim, co wynika z ogólnych uwarunkowań rozwoju technologicznego i postępu całej ludzkości. Rozwinę to w głównej części artykułu,. W tym miejscu chcę zwrócić uwagę, że obecnie na pierwszy plan wysunął się, za sprawą surowców naturalnych, braku jasnych uregulowań wielostronnych i trudności w interpretacji niektórych norm prawa międzynarodowego drugi z wymienionych, problem Arkyki.

Niemniej, w szerokim rozumieniu, dobra wspólne dotyczą nie tylko obszarów, ale również poszczególnych elementów środowiska naturalnego, będących pod jakąś formą kontroli zorganizowanych $\mathrm{w}$ ramach struktur państwowych społeczeństw od starożytności, przy czym regulacje prawne w tej materii stały się szczególnie ważne $\mathrm{w}$ $\mathrm{XX}$ wieku, a w konsekwencji mogą być, wraz z rozwojem technologicznym, coraz bardziej istotne. Jako przykłady można wskazać dno, morskie, atmosferę. Są one objętę umowami międzynarodowymi, w szczególności aktywność ludzka w nich. Umowy te mają różny stopień rygoryzmu, częściowo kwestie te są regulowane także w umowach dotyczących zakazu użycia konkretnych rodzajów broni, np. atomowej. Niezależnie od toczącej się w wielu środowiskach debat, tak nauk społecznych, jak i nauk przyrodniczych i ścisłych, w jakim stopniu człowiek jest w ogóle w stanie wpływać na otaczające go środowisko, należy przyznać, że istnieje cały przekrój opinii, począwszy od takich, które określają taki wpływ jako marginalny, do takich, które uważają go za bardzo wysoki. Moja hipoteza jest taka, że istnieje wpływ, jednak na chwilę obecną niedookreślony, a w związku z tym wysiłek, żeby zajmować się tym tematem w zakresie kompetencji poszczególnych dyscyplin, jest bardzo istotny.

Metody badawcze, jakie uważam za najbardziej właściwe przy badaniu zakreślonej powyżej problematyki, to analiza dotychczasowych umów międzynarodowych, a przypadku kiedy nie istnieją, analiza przyczyn ich braku, następnie zaś, odniesieniu stanu formalnego do faktycznie obserwowanego. Pomocne $\mathrm{w}$ takim przypadku mogą być między innymi raporty specjalizujących się $\mathrm{w}$ danej tematyce organizacji międzynarodowych, nie tylko tych o charakterze stricte międzyrządowym, analiza danych ekonomicznych i technicznych, a także szereg innych czynników, o czym dalej.

Zasadniczym celem artykułu jest przedstawienie stanu bieżącego dla przyjętego obszaru badawczego oraz przedstawienie rekomendacji i własnych prognoz.

\section{Ogólne uwarunkowania}

Ukształtowany po 1945 roku układ dwublokowy miał ważne implikacje dla rozstrzygania sporów terytorialnych, pozostałości po czasie kolonializmu, lub quasi kolonializmu w latach 20 i $30 \mathrm{XX}$ wieku. Pojawienie się broni atomowej w arsenałach światowych mocarstw całkowicie zmieniło sytuację, nie tylko geopolityczną, ale również $\mathrm{w}$ odniesieniu do obszarów nieuregulowanych $\mathrm{w}$ rozumieniu traktatów międzynarodowych.

Wzajemna nieufność nie w pełni przełożyła się na ten problem, gdyż, a być może dzięki tej nieufności, rozpoczęły się poszukiwania kompromisu na wielu płaszczyznach stosunków międzynarodowych. Oczywiste jest, że te poszukiwania wynikały mniej z pobudek dobra ludzkości, co z powodów uzasadnienia własnych postaw ideologicznych i interesów. Warto jednak zauważyć, że paradoksalnie wzajemna nieufność i doniesienia o hipotetycznej przewadze wroga wpłynęły na chęć 
Piotr Motyl

ISSN 2078-4333. Вісник Львівського університету. Серія міжнародні відносини. 2018. Випуск 45

zawierania omawianych $\mathrm{w}$ tym artykule porozumień. Wyścig zbrojeń, $\mathrm{w}$ tym również niżej omawiany wyścig w kosmos, zaczął napędzać gospodarki. Mimo wszystko, wyścig miał to do siebie, że fluktuował m.in. ze względu na czynniki wewnętrzne państw w niego zaangażowanych i ogólną sytuację międzynarodową. Same zmiany przywódców państw, w szczególności w USA i ZSRR, dynamizowały lub spowalniały rywalizację, a należy zauważyć, że przywódcy ci nie funkcjonowali w oderwaniu od szeroko rozumianego aparatu państwowego, doradców, naukowców itd. Trzeba też zauważyć $\mathrm{w}$ związku $\mathrm{z}$ tym, że prawnomiędzynarodowy status omawianych $\mathrm{w}$ artykule obszarów był $\mathrm{w}$ dużej mierze pochodną tak relacji politycznych, jak i przewidywań co do tempa rozwoju techniki, m.in. kosmicznej. Z wyżej wymienionych powodów co najmniej kilka umów międzynarodowych dotyczących ochrony dóbr wspólnych ludzkości albo powstało w niewłaściwym czasie, co do zasady za wcześnie, uprzedzając rozwój technologiczny o kilka dziesięcioleci, albo na takim poziomie ogólności, że w praktyce niewiele można w oparciu o takie umowy wyegzekwować.

Biorąc pod uwagę ostatnie dziesięciolecie XX wieku i pierwsze dwa XXI, trzeba zwrócić uwagę, że w pierwszym okresie po rozpadzie układu dwublokowego i ewolucji systemu międzynarodowego w kierunku wielobiegunowości, można było odnosić wrażenie, że współpraca zastępuje rywalizację. Okazało się to jednak nieprawdą, gdyż światowe wydatki zbrojeniowe po spadkach zaczeły wykazywać, w zależności od przyjętej metodologii, tendencję wzrostową od około 1999 roku, z lekkim wyhamowaniem około roku 2012 [1] [2] [3, s. 40-41]. Dodatkowo, np. w zakresie programów nuklearnych, konstrukcji rakiet balistycznych, programów kosmicznych (przynajmniej dwa ostatnie zagadnienia blisko ze sobą związane), pojawiły się nowe państwa, o ambicjach potęg regionalnych jak Iran, ale też globalnych - przykładem może być chiński program kosmiczny.

Reasumując, moim zdaniem problematyka ochrony dóbr wspólnych ludzkości, przed takimi czynnikami jak wykorzystanie, niszczenie zasobów naturalnych, militaryzacja, nuklearyzacja, zanieczyszczenie, w tym odpadami radioaktywnymi itd., wchodzi w chwili obecnej w nową fazę, a dynamiczny rozwój technologiczny niewątpliwie wymusi modyfikację obecnego stanu uregulowań, chociaż trudno ocenić, czy będzie tak szybki, że spowoduje taką konieczność za 10 lat, 20 lat, czy więcej.

\section{Przegląd wg regionów i zagrożeń}

3.1 Antarktyda. $Z$ przyrodniczego punktu widzenia Antarktyda jest jednym z ważniejszych obszarów świata. Jak wspomniałem wyżej, w chwili obecnej żadne państwo nie rozciąga swojej suwerenności nad żadnym jej obszarem. Nie zmienia to faktu, że są takie, które ze względów historycznych (odkrycia) lub geograficznych (niewielka odległość od własnego terytorium) mają jednak w tym względzie nie w pełni jasne zamiary.

Problem Antarktydy (Antarktyki) został rozwiązany pod względem prawnomiędzynarodowym relatywnie szybko po zakończeniu II Wojny Światowej Układ regulujacy stosunki na tym obszarze został otwarty do podpisu w 1959 roku, a wszedł w życie w 1961 [4]. Układ w sprawie Antarktydy nie jest co prawda mocno sformalizowany jeżeli chodzi o możliwości wymuszania na państwach konkretnych 
zachowań bądź powstrzymywania przed nimi, posiada jednak istotny wkład w rozwój bezpieczeństwa międzynarodowego, m.in. za sprawą zgody co do denuklearyzacji tego obszaru. Jest to więc strefa wolna od broni jądrowej stworzona nieco inaczej niż pozostałe, tj. Ameryki Łacińskiej i Karaibów, Azji Środkowej, Azji Południowowschodniej, Afryki, Południowego Pacyfiku.

Na mocy układu przewidziano również konsultacje państw-stron, począwszy od demilitaryzacji, po ochronę środowiska [5]. Jednym z filarów tego niewielkiego pod względem objętościowym dokumentu jest również współpraca naukowa. Precyzyjnie rzecz ujmując Traktat, zgodnie z brzmieniem Artykułu VI, obejmuje całe terytorium położone na południe od 60 równoleżnika południowej szerokości geograficznej [6].

\section{Ilustracja 1.}

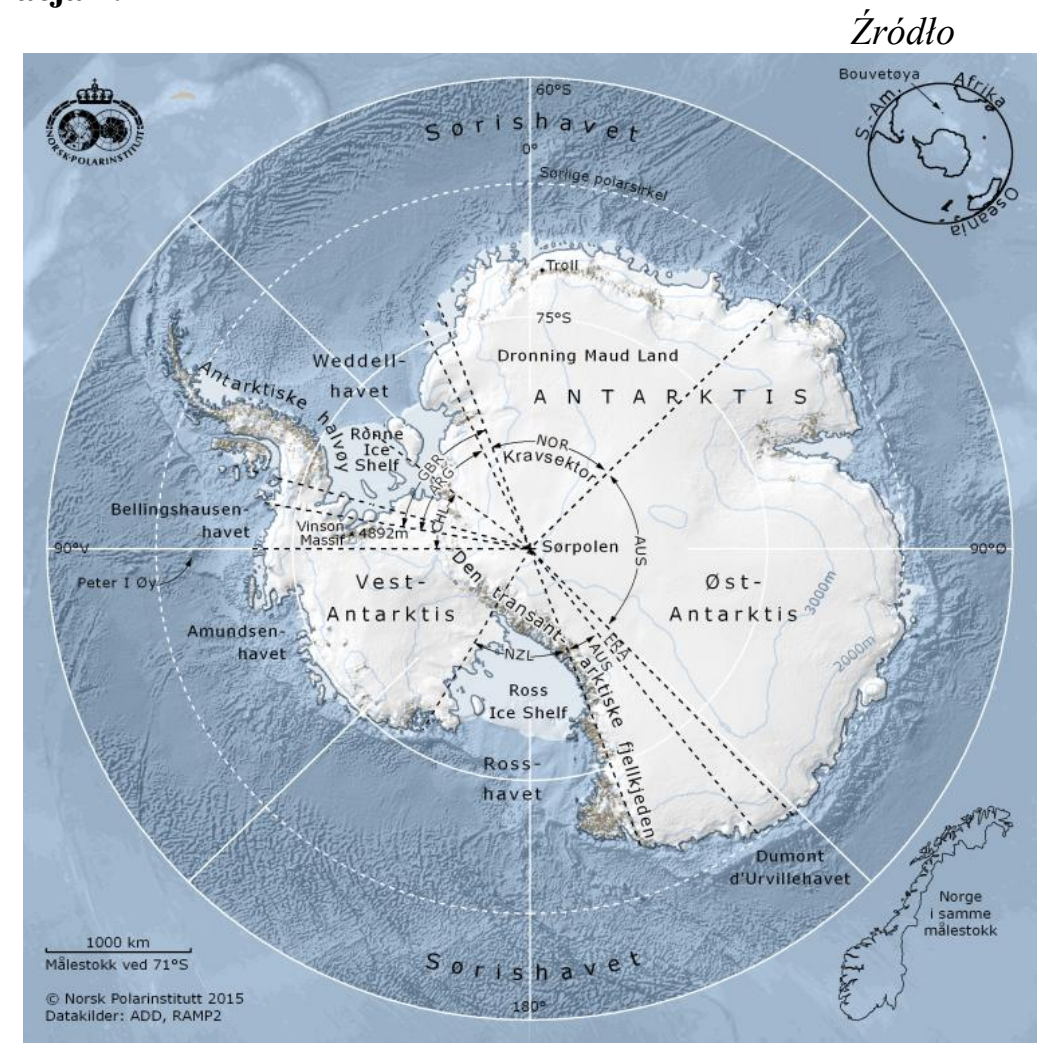

www.npolar.no

3.2. Arktyka. Zasadniczą kwestią odróżniającą problematykę Arktyki jest fakt, że nie ma tutaj traktatowego odpowiednika dla Układu w sprawie Antarktydy, choćby w opisanej wyżej ogólnikowej formie. Roszczenia są w tym przypadku podnoszone niejednokrotnie oficjalnie, czasami demonstracyjnie, np. poprzez zatykanie flagi państwowej w dnie morskim. Próby rozciągania suwerenności państwowej na ten obszar nie są celem samym w sobie, gdyż $\mathrm{w}$ istocie tym co powoduje znaczne zainteresowanie nim są surowce naturalne, przede wszystkim ropa naftowa i gaz ziemny, szacunkowo jest to w granicach 20 procent całych światowych zasobów [7], 
Piotr Motyl

ISSN 2078-4333. Вісник Львівського університету. Серія міжнародні відносини. 2018. Випуск 45

chociaż można spotkać się też z nieco większymi liczbami. Dodatkowym czynnikiem wpływającym na ważność regionu są północne szlaki komunikacyjne. Zakładając, że koncepcja topnienia lodowców ma charakter permanentny, a nie przejściowy, wtedy połączenie ze sobą tych czynników, czyli de facto ułatwienie dostępu do surowców na półkuli północnej, istotnie może jeszcze wzrastać.

W kontekście Arkyki nie sposób nie zauważyć dysproporcji sił zainteresowanych nią państw, również militarnych, a także zdolności do samej projekcji siły. Zdecydowanie inne możliwości posiada Rosja, Kanada, czy Dania. Jednocześnie nie można pominąć faktu, że istnieją formy zinstytucjonalizowanej współpracy w tym regionie. Trzeba tu wskazać na Radę Państw Arktycznych. W jej skład wchodzą Kanada, Dania, Finlandia, Islandia, Norwegia, Rosja, Szwecja i USA, a także przedstawiciele autochtonicznej ludności. Radę wspierają w pracy grupy robocze [8]. Niemniej rada ma mimo wszystko charakter forum współpracy, a nie organizacji międzynarodowej mogącej w znacznym stopniu kontrolować to co dzieje się na tym obszarze, w tym rzeczywiste rodzaje aktywności militarnej państw. W chwili obecnej spór w tym regionie świata ma również tę cechę, że zdolności do działania $\mathrm{w}$ tak specyficznym regionie są dopiero przez zainteresowane podmioty rozwijane, w dużej mierze ma też charakter badania reakcji innych państw, nie tylko $\mathrm{z}$ tego regionu, na kolejne działania, czy też prób narzucenia własnej interpretacji wybranych norm prawa międzynarodowego. Ponadto interpretacje takie, np. dotyczące szelfu kontynentalnego, muszą mieć jakiś stopień uzasadnienia w badaniach geograficznych, co z kolei powoduje, że należy znowu cofnąć się do zagadnień zdolności do prowadzenia działań, choćby naukowych, na tym obszarze.

3.3. Przestrzeń kosmiczna. Tak jak wspomniałem wyżej, układy dotyczące przestrzeni kosmicznej podpisywano jeszcze w czasie Zimnej Wojny, uprzedzając znacznie to, jaką aktywność $\mathrm{w}$ przestrzeni kosmicznej będzie można prowadzić $\mathrm{z}$ technicznego i ekonomicznego punktu widzenia. Pierwszy z nich, Traktat o regułach rządzących aktywnością państw w eksploracji i użyciu przestrzeni kosmicznej, włącznie z Księżycem i innymi ciałami niebieskimi, został otwarty do podpisu i wszedł w życie w roku 1967 i liczy 105 państw-stron. Drugi, Porozumienie rządzące zachowaniem państw na Księżycu i innych ciałach niebieskich, został otwarty do podpisu 1979, a wszedł w życie dopiero w roku 1984. Liczy tylko 18 państw-stron [9].

Pierwszą znamienną rzeczą jest właśnie różnica w liczbie państw-stron. Istotnie, dynamiczny rozwój techniki kosmicznej i jednocześnie wyścigu w tym zakresie w latach $60 \mathrm{XX}$ wieku mógł skłaniać do formułowania bardzo śmiałych prognoz w tym kontekście. Na przełomie lat 70 i 80 sytuacja wyglądała już zupełnie inaczej, gdyż jedno $\mathrm{z}$ dwóch mocarstw, tj. ZSRR, zaczął wchodzić w kryzys ekonomiczny. W pierwszym $\mathrm{z}$ trakatów, wynegocjowanym na kilku płaszczyznach, nie tylko amerykańsko-radzieckiej, gwarantowano współpracę, wymianę doświadczeń i osiągnięć naukowych, poprawę wzajemnych stosunków. Wprowadzono zakaz rozciągania suwerenności państwowej $\mathrm{w}$ kosmosie, ustalono zakaz militaryzacji przestrzeni kosmicznej (m.in. personel, broń nuklearna, fortyfikacje). Nieprecyzyjnie, ale wskazano też na możliwości przeprowadzania wzajemnych inspekcji. Jak wynika $\mathrm{z}$ powżyszego zarysu, wiele $\mathrm{z}$ tych zasadniczych postanowień miało charakter 
życzeniowy. O ile współpraca amerykańsko-rosyjska $\mathrm{w}$ badaniu przestrzeni kosmicznej istnieje do dzisiaj, mimo napięć w stosunkach między tymi państwami, to trudno sobie wyobrazić pełne przekazywanie wiedzy w szczytowym okresie zimnej wojny. Fortyfikacje, personel wojskowy, inspekcje itd., do dzisiaj pozostały jeszcze bliżej sfery science-fiction, chociaż nie można zapominać, że m.in. Rosja i Chiny rzeczywiście przejawiają niewielką aktywność w testowaniu swoich programów kosmicznych również i pod takim kątem.

Drugi, późniejszy Układ, uściślił przede wszystkim pojęcia zawarte w poprzednim. Podobnie jak w pierwszym przypadku uprzedził rzeczywisty przebieg wydarzeń i rozwój zdolności technicznych oraz finansowych państw w omawianym temacie o kilkadziesiąt lat.

3.4. Inne zagadnienia ochrony środowiska. Kwestią do której chciałbym się odnieść w tym podrozdziale jest broń masowego rażenia. Zarówno w przypadku broni, biologicznej, chemicznej i nuklearnej istnieją międzynarodowe Traktaty mające na celu ochronę środowiska przez skutkami ich działania. Najmocniej regulowane są dwa ostatnie przypadki. Jeżeli chodzi o broń nuklearną istnieje pięć wymienionych wyżej stref wolnych od tej broni. Dochodzą do tego jeszcze zakazy wynikające $z$ innych układów. Wyżej wspomniałem o zakazach wynikających $\mathrm{z}$ układów dotyczących Antarktydy i przestrzeni kosmicznej. Patrząc bardziej przedmiotowo, mamy $\mathrm{w}$ tym zakresie jeszcze Układ o zakazie umieszczania takiej broni w dnie morskim i oceanicznym oraz Układ o zakazie prób z bronią nuklearną w przestrzeni kosmicznej i pod wodą. Ten ostatni nie zakazuje ich w pełni, niemniej od 1996 pozostaje otwarty do podpisu Układ dotyczący pełnego zakazu prób z tą bronią, mimo tego, że ma 166 państw-stron, jest bolkowany przed wejściem w życie przez bardziej szczegółowe kwestie polityczne, m.in. brak ratyfikacji przez USA, Chiny, a z silniejszych państw regionalnych np. Egiptu, Izraela, Iranu.

Kwestie użycia broni chemicznej są również dobrze zabezpieczone, tak Konwencją o zakazie szeroko rozumianego jej użycia, jak i powołaną na mocy Konwencji organizacją międzynarodową (OPCW). Niemniej, jak pokazuje m.in. konflikt syryjski, czy domniemane rosyjskie próby otruć przeciwników politycznych na terytorium Wielkiej Brytanii, trudniej jest zapanować nad użyciem takich substancji niż ma to miejsce w przypadku broni atomowej. Niewątpliwie wynika to również z faktu, że łatwo uzmysłowić sobie konsekwencje użycia głowic atomowych, a jak sądzę trudniej broni chemicznej. Podobnie jak w przypadku broni biologicznej, jest to nie w pełni słuszne, ponieważ o ile współcześnie użycie na przykład broni chemicznej rzeczywiście jest kojarzone z konfliktami lokalnymi, wojnami domowymi itd. to generalnie rzecz biorąc nie musi tak być zawsze.

Zakaz użycia broni biologicznej został wprowadzony również na mocy Konwencji, niemniej w odróżnieniu od zakazów dotyczących broni atomowej i chemicznej, Konwencja posiada duży poziom ogólności. W praktyce natomiast zagadnienie jest jeszcze trudniejsze, bo poziom przejrzystości jest w tym przypadku bardzo niski i trudno ocenić kto tak naprawdę posiada taką broń, jaki rodzaj, w jakich ilościach. Często «liczenie» sprowadza się do przekazywanych przez media wzajemnych oskarżeń, głównie amerykańsko-rosyjskich, ale w gronie 
Piotr Motyl

ISSN 2078-4333. Вісник Львівського університету. Серія міжнародні відносини. 2018. Випуск 45

nieprzewidywalnych w pełni pod tym względem znajdują się też inne. W listopadzie 2016 roku miała miejsce VIII Konferencja Przeglądowa Konwencji o broni biologicznej. Szczegółowe deklaracje kilkunastu państw co do wykonywania jej postanowień można znaleźć w jednym z jej końcowych dokumentów, dostępnych na stronie Biura Narodów Zjednoczonych w Genewie (UNOG) [10].

\section{Podstawowe wyzwania w zakresie ochrony dóbr wspólnych ludzkości}

W tej części pracy odniosę się, podsumowując jednocześnie część powyższych rozważań, do tego, jakie wyzwania uważam za kluczowe dla ochrony wspólnych dóbr ludzkości. W pierwszej kolejności trzeba mieć na uwadze zróżnicowany pod względem formalnoprawnym status poszczególnych obszarów, ale również poszczególnych aspektów w zakresie ochrony środowiska. Mamy w tym miejscu dość szeroką przestrzeń od regulacji minimalnych, po takie, których rzeczywiście, z punktu widzenia zainteresowanych państw, trudno nie przestrzegać. Zróżnicowanie rygoryzmu jest również często związane z naturalnym zróżnicowaniem państw-stron, pod względem historycznym, kulturowym, gospodarczym itd. Dodatkowo, jak już wskazywałem, nie wszystkie porozumienia międzynarodowe są adekwatne do zagrożeń w tym względzie, że mogą zostać przyjęte zbyt późno lub zbyt wcześnie, co spowoduje albo konieczność reagowania po fakcie, albo sprowadzi taki dokument do interesującego zbioru myśli.

Bardzo ważne są takie czynniki jak stopień efektywności umów, inaczej rzecz ujmując jest to pytanie o to, jak wygląda przestrzeganie postanowień poszczególnych traktatów, umów i konwencji, tak w odniesieniu do konkretnych państw, jak i do państw-stron danego porozumienia ogółem. Jednocześnie nie jest zawsze rzeczą oczywistą, że duży rygor, w tym m.in. inspekcje, muszą dawać lepsze rezultaty, chociaż istotnie, rozumując na pewnym poziomie ogólności, łatwiej ukryć pewne czynności jeżeli ich międzynarodowa weryfikacja opiera się tylko i wyłącznie na informacjach przedstawianych przez dane państwo. W tym miejscu należy też jednak zauważyć, że gdyby nie trochę mniej sformalizowany sposób ujawniania przez państwa własnych działań, prawdopodobne jest, że część porozumień o charakterze opisywanym w tym artykule mogłaby nie powstać w ogóle.

Ostatnią, nie mniej kluczową od efektywności umów kwestią, jest rola organizacji międzynarodowych. Znaczna część porozumień rozbrojeniowych, chroniących środowisko itd., odwołuje się w ostateczności, tj. w sytuacji całkowitego impasu, do którejś z organizacji międzynarodowych, najczęściej do Zgromadzenia Ogólnego i Rady Bezpieczeństwa ONZ. Niestety, jak pokazują ostatnie lata, ten ostatni organ przestaje coraz bardziej spełniać swoją rolę strażnika międzynarodowego pokoju i bezpieczeństwa, a przypomina bardziej miejsce wzajemnego rozgrywania (ewentualnie blokowania) własnych żywotnych interesów przez członków z prawem veta. Wybierając $\mathrm{z}$ powyższych wyzwań, mając wskazać na najpoważniejsze, wzskazałbym na dwa ostatnie, tj. efektywność wykonywania umów, a szczególnie w przypadkach omawianych w tym artykule, ogromną rolę ONZ.

V. Wnioski. W części końcowej chciałbym skupić się na zasadniczych dla mnie wnioskach.

1. Ochrona dóbr wspólnych ludzkości nie jest pełna. Potrzebne są nowe 
inicjatywy w zakresie m.in. Arktyki, ale również rozwijanie i modyfikowanie tego co udało się stworzyć dotychczas, tak aby ochrona tych dóbr mogła być jeszcze bardziej efektywna. Nie postulowałbym w związku z tym radykalnych zmian na poziomie samych uregulowań prawnomiędzynarodowych, gdyż uważam, że akurat na poziomie traktatów, powołanych nimi organizacji, stref, reżimów, system funkcjonuje dobrze. Można powiedzieć, że znacznie lepiej niż na poziomie ONZ.

2. Nie mam wątpliwości, że traktaty pozostające dzisiaj bliżej sfery fantastyki, w nieodległej perspektywie czasowej również będą musiały zostać zmodyfikowane, na co wpłynie przede wszystkim rozwój możliwych do wykorzystania technologii. W tym kontekście warto zwrócić uwagę na działalność na bieżąco monitorującego tę problematykę i tworzącego interesujący zbiór dokumentacji Biura Narodów Zjednoczonych ds. Przestrzeni Kosmicznej - UNOOSA [11].

3. Część najważniejszych organizacji międzynarodowych musi zostać poddana głębokim reformom, gdyż rosnące oczekiwania względem własnej pozycji międzynarodowej kolejnych dynamicznie rozwijających się państw, będą prowadziły to dalszych problemów decyzyjnych, tak jak we wskazanym przykładzie RB ONZ. Innymi słowy organizacje, które miały za zadanie funkcjonować skutecznie w realiach $\mathrm{XX}$ wieku, mogą nie być w stanie sprostać obiektywnym zmianom w stosunkach międzynarodowych, choćby rozwojowi a co za tym idzie wzrostowi aspiracji w państwach Ameryki Południowej, Afryki, Azji.

\section{BIBLIOGRAFIA}

1. World Military Expenditure 1988-2017, https://www.sipri.org/research/armament-anddisarmament/arms-transfers-and-military-spending/military-expenditure, dostęp z dnia 30.05.2018.

2. World Military Spending, http://www.globalissues.org/article/75/world-military-spending, dostęp z dnia 30.05.2018.

3. Likowski M., Wyhamowanie wyścigu zbrojeń, «Raport WTO» 2012, nr 5, s. 40-41.

4. Baza danych UNODA, http://disarmament.un.org/treaties/ dostęp z dnia 02.06.2018.

5. Układ w sprawie Antarktydy z dnia 1 grudnia 1959 r., Dziennik Ustaw PRL, Załącznik do nru 46, poz. 237 i 239 z dnia 21 października $1961 \mathrm{r}$.

6. Ibidem.

7. Budzik P., Arctic Oil and Natural Gas Potential, http://www.arlis.org/docs/voll/ AlaskaGas/Paper/Paper_EIA_2009_ArcticOilGasPotential.pdf, dostęp z dnia 06.06.2018.

8. Arctic Council, www.artic-council.org, dostep z dnia 06.06.2018.

9. Teksty Traktatów dotyczących przestrzeni kosmicznej i dane liczbowe są dostępne w bazie UNODA, http://disarmament.un.org/treaties/ dostęp z dnia 02.06.2018.

10. BWC/CONF.VIII/INF.2 - Compliance by States Parties with their Obligations under the Convention - Background Information by the Implementation Support Unit, http://www.unog.ch, dostęp z dnia 07.06.2018.

11. United Nations Office for Outer Space Affairs, Documents and resolutions databse, http://www.unoosa.org/oosa/documents-and-resolutions/search.jspx?view=documents\& $\mathrm{f}=\mathrm{oosa}$ Document.doctags.doctag_s\%3ACOPUOSRDOCS, dostęp z dnia 06.06.2018. 


\title{
МАЙБУТНЄ МІЖНАРОДНОГО ВРЕГУЛЮВАННЯ ЩОДО СПІЛЬНИХ БЛАГ ЛЮДСТВА
}

\author{
Пйотр Мотиль \\ Університет ім. Миколи Коперніка в Торуні, \\ вул. Гагаріна, 11, м. Торунь, Польща, 87-100, \\ e-mail plm.motyl@interia.pl
}

\begin{abstract}
Майбутнє спільних благ людства та міжнародного права, яке регулює їх захист, стає важливою сферою наукових досліджень. Угоди та неформальні домовленості, що діяли у XX столітті, не видаються достатніми у XXI столітті. На мій погляд, у короткостроковій перспективі такі проблеми, як гонка за доступ до природних ресурсів Арктики, Антарктики чи космічного простору, стануть можливо ще важливішими завдяки швидкому розвитку технологій та змін у структурі міжнародних відносин.
\end{abstract}

Не лише конкретні території, а також окремі райони навколишнього середовища $є$ предметом уваги і потребують охорони, наприклад, морське дно, радіоактивні відходи, а також різні види зброї, які можуть привести до значного знищення, такі як хімічна, біологічна та ядерна зброя. Ступінь обов'язкового регулювання часто відрізняється від просто декларативного до значно високого. У статті показано причини відмінностей.

Як зазначено вище, поточний стан обговорюваних питань має своє генезу в минулому, і тому ця перспектива аналізу є дуже важливою, починаючи принаймні з міжвоєнного періоду, через «Холодну війну», останнє десятиліття XX ст. та початок XXI ст. Політика, економіка та технологічний розвиток призвели до того, що частина нормативних положень була створена надто рано, як результат побоювання розв'язання нової світової війни, відображенням майбутніх намірів тощо. Проте хоч час від часу суперництво, наприклад, двоблокове, давало позитивні результати 3 досліджуваної проблеми, на мою думку, не було єдиної позитивної чи негативної тенденції, подібно до стану міжнародних стосунків, які в цей період змінювалася неодноразово.

У статті я проаналізовано вищезазначені проблеми та представлено висновки, які я вважаю найбільш суттєвими. Основним методом дослідження, який використано в статті, $є$ порівняння формальних та неформальних домовленостей (якщо таких не існує, я намагаюся пояснити, чому) 3 тим, що можна спостерігати на практиці. Аналіз спирається на статистичні дані, звіти, інформацію, доступну із повідомлень ЗМІ.

Ключові слова: спільні блага; людство; міжнародне право; міжнародна безпека; охорона навколишнього середовища.

\section{THE FUTURE OF THE INTERNATIONAL GOVERNANCE ON JOINT GOODS}

\section{Piotr Motyl}

\author{
Nicolaus Copernicus Uniwersity in Toruń, \\ 11, Gagarina Str., Toruń, Poland, 87-100, \\ e-mail plm.motyl@interia.pl
}

The future of the common goods of the mankind and the international law that secures them, starts to be an important scientific problem. Treaties and informal regulations from the XX century does not seem to be enough in the XXI century. In my opinion, within a short period of time, such a problems as Arctic race for raw materials, Antartics or Outer Space, will become even more important, beacuse of rapid technical development and changes in the structure of the international relations.

Not only territories, but also different fields of the environment are the subject of concerns, for example seabed, radioactive wastes, as well as different kinds of weapons, that can be dectructive, for example, chemical, biological or atomic. The level of strictness of the regulations differs - from declarative to high. In the article I point at the reasons of the differences. 
As it was suggested above, the present state of these problems has its origins in the past, and also this perspective of analysys is very important, starting at least from the interwar peroid, through The Cold War, the last decade od the XX century and the beginning of the XXI. Politics, economy, technical develepment, rusulted in the fact that some of the treaties and regulations were created too fast, becoming an example of fear of a next war, wishful thinking. However, from time to time, the rivalry had also postitive results, in my opinions there was no one positive or negative tendency, similary to the state of the international relations it was changing many times.

In this article I analyse these problems and make conclusions that I find the most important. The main methods I use is comparison of the formal acts and informal regulations (or if they do not exist I try to explain that) with this what can be observed nowadays. The anylysis is supported by international statistics, reports, also by what was found out by the media.

Key words: common goods; mankind; international law; international security; environment protection. 